\title{
Cyclic AMP: A Potent Inhibitor of DNA Synthesis in Cultured Arterial Endothelial and Smooth Muscle Cells
}

\author{
R.W. Stout \\ Department of Geriatric Medicine, The Queen's University of Belfast, Northern Ireland
}

\begin{abstract}
Summary. The effect of dibutyryl cyclic AMP on DNA synthesis was studied in cultured human umbilical endothelial cells and rat aortic smooth muscle cells. Dibutyryl cyclic AMP $\left(2 \times 10^{-4} \mathrm{~mol} / \mathrm{l}\right)$ inhibited DNA synthesis in both arterial cell types when they were grown in medium supplemented with whole serum or with platelet poor serum, but had no effect in the absence of serum. An effect was seen one hour after the addition of the nucleotide, and the threshold concentration was between $2 \times 10^{-6}$ and $2 \times 10^{-5} \mathrm{~mol} / 1$. These results may have relevance to the interaction of platelets and insulin with the arterial wall in the development of atherosclerosis in diabetes.
\end{abstract}

Key words: Cyclic AMP, dibutyryl cyclic AMP, endothelial cells, smooth muscle cells, artery, DNA synthesis, platelets, diabetes, atherosclerosis

Atherosclerosis is a disease of the inner part of the arterial wall. In this part of the artery two cells predominate, endothelial cells, which line the inner surface of the vessel, and smooth muscle cells. Modern theories on the pathogenesis of atherosclerosis assign important roles to both these cells [1]. The endothelial cell is thought to act as a barrier preventing the constituents of circulating blood from entering the inner part of the artery. It is postulated that an early change in the development of atherosclerosis is an injury or alteration to the endothelial cell barrier allowing plasma constituents to enter the inner part of the arterial wall and act on the smooth muscle cells. Plasma constituents stimulate arterial smooth muscle cells to proliferate. If the stimulus is temporary, repair of the arterial damage occurs but if the stimulus continues, the cells become filled with lipid and eventually an atheromatous plaque develops.

A number of factors have been proposed to have a role in the early development of the arterial lesion. These include platelet factors [2], lipoproteins [3] and insulin [4]. Both platelet and insulin action are related to the activity of cyclic adenosine $3^{\prime} 5^{\prime}$-monophosphate (cyclic AMP) and situations associated with insulin overactivity [5] and with platelet adhesiveness [6] are associated with decreased intracellular cyclic AMP. Cyclic AMP may thus be a common factor linking the actions of these factors. This paper describes the effect of dibutyryl cyclic AMP (db-cAMP) on DNA synthesis in cultured arterial cells. Dibutyryl cyclic AMP was chosen as it is said to pass through cell membranes more readily than cyclic AMP itself [7].

\section{Materials and Methods}

Culture media, trypsin and fetal calf serum were obtained from Gibco Biocult, Paisley, Scotland, UK and Falcon plastic culture dishes and flasks from Becton Dickinson, Wembley, Middlesex, UK. Collagenase (Type I from Cl. histolyticum [Worthington]) was obtained from Millipore, London, UK. Human serum was obtained from the Northern Ireland Blood Transfusion Service, Belfast, UK. It was pooled from at least 20 donors and was filter sterilized before use. Platelet-poor serum was prepared according to the method of Rutherford and Ross [8] as described [9]. Isotopes were obtained from the Radiochemical Centre, Amersham, UK. dbcAMP was purchased from Sigma Chemicals, London and dissolved in a $4 \%$ bovine albumin solution.

\section{Cell Culture Techniques}

Human endothelial cells were cultured from umbilical vein by a modification [9] of the methods of Jaffe et al. [10] and Gimbrone et al. [11]. Briefly, umbilical cord was obtained within $12 \mathrm{~h}$ of delivery. The umbilical vein was identified, canulated and washed with Dulbecco's phosphate buffered saline (PBS) to remove any residual 
Table 1. Effect of dibutyryl cyclic AMP $\left(2 \times 10^{-4} \mathrm{~mol} / \mathrm{l}\right)$ on DNA synthesis in cultured rat arterial smooth muscle cells

\begin{tabular}{|c|c|c|c|c|}
\hline Medium & Control & db-cAMP & $t$ value & $p$ value \\
\hline \multirow[t]{2}{*}{ With $10 \%$ calf serum } & $1,373,966 \pm 81,557$ & $\begin{array}{c}253,051 \pm 22,498 \\
(18 \%)\end{array}$ & 13.25 & $<0.0005$ \\
\hline & $626,280 \pm 75,636$ & $\begin{array}{c}77,885 \pm 2,516 \\
(12 \%)\end{array}$ & 7.25 & $<0.0005$ \\
\hline \multirow[t]{2}{*}{$\begin{array}{l}\text { With } 10 \% \text { platelet-poor } \\
\text { human serum }\end{array}$} & $13,453 \pm 1,557$ & $\begin{array}{l}3,389 \pm 217 \\
(25 \%)\end{array}$ & 6.40 & $<0.0005$ \\
\hline & $19,370 \pm 1,896$ & $\begin{array}{c}5,485 \pm 1,307 \\
(28 \%)\end{array}$ & 6.03 & $<0.0005$ \\
\hline \multirow[t]{2}{*}{ With no serum } & $9,977 \pm 3,265$ & $\begin{array}{l}5,952 \pm 1,790 \\
(60 \%)\end{array}$ & 1.08 & $>0.15$ \\
\hline & $7,954 \pm 711$ & $\begin{array}{l}5,630 \pm 260 \\
(71 \%)\end{array}$ & 3.07 & $<0.01$ \\
\hline
\end{tabular}

Each value is the mean of six replicate plates. Results are expressed as counts $\min ^{-1} \mathrm{mg}$ cell protein ${ }^{-1}$ (mean \pm SEM). Figures in parentheses represent the values in the cells exposed to db-cAMP expressed as a percentage of the values in the control cells

Table 2. Effect of time of exposure to db-cAMP $\left(2 \times 10^{-4} \mathrm{~mol} / \mathrm{l}\right)$ on DNA synthesis in cultured rat arterial smooth muscle cells grown in medium with $10 \%$ fetal calf serum

\begin{tabular}{llr}
\hline Time (h) & DNA & $(\%)$ \\
\hline 0 & 62,666 & 100 \\
1 & 37,973 & 61 \\
2 & 39,429 & 63 \\
3 & 41,806 & 67 \\
4 & 27,298 & 44
\end{tabular}

Each value is the mean of two replicate plates. Results are expressed as counts $\min ^{-1} \mathrm{mg}$ cell protein ${ }^{-1}$

Table 3. Effect of different concentrations of db-cAMP on DNA synthesis in cultured rat arterial smooth muscle cells grown in medium with $10 \%$ fetal calf serum

\begin{tabular}{crr}
\hline $\begin{array}{l}\text { db-cAMP } \\
(\mathrm{mol} / 1)\end{array}$ & DNA & $(\%)$ \\
\hline 0 & $17,816 \pm 666$ & 100 \\
$2 \times 10^{-6}$ & $19,565 \pm 492$ & 110 \\
$2 \times 10^{-5}$ & $11,583 \pm 277$ & 65 \\
$2 \times 10^{-4}$ & $4,270 \pm 170$ & 24 \\
\hline
\end{tabular}

Each value is the mean \pm SEM of three replicate plates. Results are expressed as counts $\mathrm{min}^{-1} \mathrm{mg}$ cell protein ${ }^{-1}$

blood. Ten $\mathrm{ml} 0.025 \%$ collagenase in PBS was then infused and the vein was clamped. After $10 \mathrm{~min}$ incubation at $37^{\circ} \mathrm{C}$, the collagenase solution was flushed out together with the endothelial cells into medium 199. After centrifugation the cell pellet was resuspended in medium 199 supplemented with $20 \%$ human serum (v/v) and plated into a $25 \mathrm{~cm}$ culture flask. Cell growth occurred in about $6 \mathrm{~h}$ and the cells reached confluency in about 5 days. Endothelial cells were identified by the presence of Weibel-Palade bodies on electron microscopy [10] and by immunofluorescence against clotting factor VIII antibodies. When the cells had filled the surface of the flask, they were freed from each other and the flask by $10 \mathrm{~min}$ exposure to trypsin $(0.5 \mathrm{~g} / 1)$ in versene buffer $(0.2 \mathrm{~g} / \mathrm{l})$ and passed into two or more new flasks. The cells were used for experiments after two or three subcultivations.
Smooth muscle cells were cultured from rat aorta by methods previously described [13]. Briefly, the aorta was removed under sterile conditions from $150 \mathrm{~g}$ male Wistar rats. The intima and media were carefully separated from the rest of the aorta, divided into small pieces and placed in plastic culture flasks with DulbeccoVogt medium supplemented with $10 \%$ fetal calf serum $(\mathrm{v} / \mathrm{v})$ at $37^{\circ} \mathrm{C}$ in a humidified atmosphere of $5 \%$ carbon dioxide in air. Cell growth was seen about 10 days after explantation and the cells grew in the hills and hollows typical of smooth muscle cells. The identity of the cells was confirmed as previously described [13]. The cells were treated by trypsinisation in a similar manner to the endothelial cells and in these studies were used after 4-12 subcultivations.

\section{Experimental}

Equal numbers of cells were plated into $1230 \mathrm{~mm}$ plastic petri dishes and were grown to near confluency in their usual growth medium. For endothelial cells this was medium 199 supplemented with $20 \%$ pooled human serum ( $\mathrm{v} / \mathrm{v})$ and for smooth muscle cells, Dulbecco-Vogt medium supplemented with fetal calf serum. When the platelet-poor serum was being tested, human serum was used for both cell types [9]. db-cAMP was then added in appropriate concentrations to the medium (see Tables) and the same volume of $4 \%$ albumen to the controls. After $24 \mathrm{~h}$ exposure to db-cAMP, $2 \mu \mathrm{Ci}$ of (methyl ${ }^{3} \mathrm{H}$ ) thymidine was added to each dish. After a further $2 \mathrm{~h}$ the medium was removed, the cells were washed in PBS and removed from the dishes by trypsinisation. DNA was extracted and its activity measured as described [9]. Protein was measured by the Lowry method [14] and the results were expressed in counts per minute per milligram cell protein. The results were analysed by Student's ' $t$ ' test.

\section{Results}

\section{Smooth Muscle Cells}

In Table 1 the results of duplicate experiments, each using six dishes in control and db-cAMP medium, are shown. db-cAMP $\left(2 \times 10^{-4} \mathrm{~mol} / \mathrm{l}\right)$ inhibited DNA synthesis by more than $80 \%$ in cells grown in whole serum and by $75 \%$ in cells grown in platelet-poor se- 
Table 4. Effect of dibutyryl cyclic AMP $\left(2 \times 10^{-4} \mathrm{~mol} / 1\right)$ on DNA synthesis in cultured human endothelial cells

\begin{tabular}{|c|c|c|c|c|}
\hline Medium & Control & db-cAMP & $t$ value & $p$ value \\
\hline \multirow[t]{2}{*}{ With $20 \%$ human serum } & $561,689 \pm 42,214$ & $\begin{array}{c}97,874 \pm 4,276 \\
(17 \%)\end{array}$ & 10.93 & $<0.0005$ \\
\hline & $157,352 \pm 5,716$ & $\begin{array}{c}106,629 \pm 7,701 \\
(68 \%)\end{array}$ & 5.29 & $<0.0005$ \\
\hline \multirow[t]{3}{*}{ With $20 \%$ platelet-poor serum } & $63,597 \pm 4,674$ & $\begin{array}{c}41,238 \pm 2,022 \\
(65 \%)\end{array}$ & 4.39 & $<0.0025$ \\
\hline & $100,301 \pm 20,598$ & $\begin{array}{c}50,768 \pm 6,294 \\
(51 \%)\end{array}$ & 2.30 & $<0.025$ \\
\hline & $60,384 \pm 10,150$ & $\begin{array}{c}6,294 \pm 543 \\
(10 \%)\end{array}$ & 5.32 & $<0.0005$ \\
\hline \multirow[t]{2}{*}{ With no serum } & $836,847 \pm 176,924$ & $\begin{array}{c}716,653 \pm 155,774 \\
(86 \%)\end{array}$ & 0.51 & $>0.30$ \\
\hline & $16,810 \pm 2,487$ & $\begin{array}{c}12,839 \pm 3,094 \\
(76 \%)\end{array}$ & 1.00 & $>0.15$ \\
\hline
\end{tabular}

Each value is the mean \pm SEM of six replicate plates. Results are expressed as counts min $^{-1}$ per mg cell protein ${ }^{-1}$. Figures in parentheses represent the values in the cells exposed to db-cAMP expressed as a percentage of the values in the control cells

Table 5. Effect of time of exposure to db-cAMP $\left(2 \times 10^{-4} \mathrm{~mol} / \mathrm{l}\right)$ on DNA synthesis in cultured human endothelial cells grown in medium with $20 \%$ human serum

\begin{tabular}{llr}
\hline Time $(\mathrm{h})$ & DNA & $(\%)$ \\
\hline 0 & 36,440 & 100 \\
1 & 31,078 & 85 \\
2 & 30,523 & 84 \\
3 & 37,077 & 102 \\
4 & 24,336 & 67 \\
\hline
\end{tabular}

Each value is the mean of two replicate plates. Results are expressed as counts min $^{-1} \mathrm{mg}$ cell protein ${ }^{-1}$

Table 6. Effect of concentration of db-cAMP on DNA synthesis in cultured human endothelial cells grown in medium with $20 \%$ human serum

\begin{tabular}{ccc}
\hline db-cAMP $(\mathrm{mol} / \mathrm{l})$ & \multicolumn{1}{l}{ DNA } & $(\%)$ \\
\hline 0 & $154,121 \pm 59,421$ & 100 \\
$2 \times 10^{-6}$ & $137,836 \pm 52,278$ & 89 \\
$2 \times 10^{-5}$ & $72,487 \pm 38,807$ & 47 \\
$2 \times 10^{-4}$ & $7,923 \pm 1,371$ & 5.1 \\
\hline
\end{tabular}

Each value is the mean \pm SEM of three replicate plates. Results are expressed as counts min $^{-1} \mathrm{mg}$ cell protein ${ }^{-1}$

rum, but had much less effect on cells grown in a serum free medium. In the latter medium, only one of the duplicate experiments showed a significant difference between db-cAMP and control. The counts in the control medium are much lower when it contained platelet-poor serum or no serum in keeping with the low level of cellular activity in these media. Table 2 shows that the effect of db-cAMP on DNA synthesis is seen $1 \mathrm{~h}$ after the cells are exposed to the nucleotide, the effect is more marked after $4 \mathrm{~h}$, and is more marked again after $24 \mathrm{~h}$ exposure (Table 1). Table 3 shows that the threshold concentration for the effect of db-cAMP on DNA synthesis in cultured arterial smooth muscle cells is between $2 \times 10^{-6}$ and $2 \times 10^{-5} \mathrm{~mol} / \mathrm{l}$.

\section{Endothelial Cells}

Tables 4, 5 and 6 show the effect of db-cAMP on DNA synthesis in cultured human endothelial cells. The inhibitory effect of the nucleotide is more variable and perhaps not as potent on endothelial cells as on smooth muscle cells (Table 4 ) but the pattern of effect on the different media is the same. The DNA counts/min in the cells in the control media are very variable between experiments, probably related to differing cell densities in the dishes. The time course of the effect of db-cAMP in endothelial cells is similar to that in smooth muscle cells (Table 5), and the effect of different concentrations of the nucleotide is also similar, although a small effect of $2 \times 10^{-6} \mathrm{~mol} / 1$ is shown.

\section{Discussion}

The results of these experiments show that db-cAMP potently inhibits DNA synthesis in cultured arterial smooth muscle and endothelial cells. Previous experiments have shown that db-cAMP antagonized the stimulating effect of insulin on the proliferation of arterial smooth muscle cells cultured from primate aortas [4]. It also inhibited sterol synthesis from acetate in cultured rat arterial smooth muscle cells [15]. Cyclic AMP has been shown to be related to the growth of a 
number of different cell lines in culture and it has been suggested that the growth response to serum constituents may be modulated by intracellular changes in cyclic AMP concentrations [16]. An inverse relationship between intracellular cyclic AMP levels and cell proliferation has been described [16]. Malignant and transformed cells have low intracellular cyclic AMP levels, and growth control and morphological appearance can be restored towards normal by addition of db-cAMP to the culture medium [7]. Most of the studies relating cyclic AMP to cell proliferation have used fibroblasts and it is not clear whether other cell types respond in the same way [17]. The present experiments suggest that growth of cultured arterial endothelial and smooth muscle cells is also influenced by cyclic AMP and that this effect is not dependent on the presence of added insulin in the medium [4]. Intracellular cyclic AMP levels do not appear to have been measured in arterial cells.

The pattern of response of endothelial and smooth muscle cells to db-cAMP was strikingly similar in view of the different responses of these cells to insulin and to the platelet derived growth factor [9]. The fact that endothelial cells bind insulin to membrane receptors [18] and respond to db-cAMP, and yet are unresponsive to insulin with respect to DNA synthesis [9] suggests that some additional factor, absent in endothelial cells but present in smooth muscle cells, mediates the activity of insulin on DNA synthesis and cell proliferation. The identity of this factor remains unknown.

Potent inhibitory effects of db-cAMP on DNA synthesis were only seen in the presence of serum. Serum was also necessary for db-cAMP to inhibit sterol synthesis in cultured smooth muscle cells [15]. This may be because the nucleotide only has effects on dividing cells. On the other hand, db-cAMP markedly inhibited DNA synthesis in smooth muscle cells exposed to platelet-poor serum despite the fact that these cells are quiescent in the absence of growth factors from platelets [2]. This suggests that some serum factor, other than one derived from platelets, is necessary for db-cAMP to have an effect on DNA synthesis. It is notable that db-cAMP had the same effect on DNA synthesis in endothelial cells and smooth muscle cells grown in platelet-poor serum despite the fact that the two cell types respond in opposite ways to this preparation of serum [9]. This is further evidence for db-cAMP interacting with a serum factor unrelated to the platelet derived growth factor.

In these experiments the endothelial and smooth muscle cells were derived from different species. Although there has been a report of successful smooth muscle cell culture from human umbilical vessels [19], the technique is difficult and attempts to reproduce it in this laboratory have been unsuccessful. Human smooth muscle cells have been grown from small pieces of tissue obtained at operation or autopsy [20] but endothelial cell culture from such tissues has not been reported. On the other hand, the rat aorta is too small to allow sufficient quantities of endothelial cells to be harvested for culture purposes. A compromise could be made by studying bovine endothelial and smooth muscle cells as techniques have been reported for culturing both types of cells from this source [21]. On the other hand, it would seem preferable to use human cells as far as possible. Smooth muscle cells have been cultured from a number of different species $[3,4$, 20-23] and in general the effects of different stimuli have been the same irrespective of the origin of the cells. Furthermore, apart from whole serum, the stimuli being studied in these experiments are not species specific.

An early event in the development of atherosclerosis is proliferation of smooth muscle cells in the arterial intima and adjacent media. Factors which control proliferation of arterial cells are of potential importance in the understanding of atherogenesis. The factors described include insulin [4] and a platelet derived growth factor [2]. Insulin has been shown to lower intracellular cyclic AMP levels in fat and hepatic cells [5] and to inhibit cyclic AMP elevations induced by other agents [5] while cyclic AMP inhibits the proliferative effect of insulin on arterial smooth muscle cells [4]. Platelet behaviour is influenced by two products of the arachidonic acid pathway, prostacyclin which causes vasodilatation and reduced platelet aggregation [24] and thromboxane $\mathrm{A}_{2}$ which has opposite effects [25]. Prostacyclin increases platelet cyclic AMP levels [24] while thromboxane $\mathrm{A}_{2}$ reduces cyclic AMP levels [25]. In diabetes, arterial prostacyclin levels have been reported to be low [26] and platelets from diabetics have increased sensitivity to aggregating agents [27]. The relation of cyclic AMP platelet and hormone action to the cellular changes in atherosclerosis and diabetes remains speculative and must be the subject of further studies. However, it has been reported that circulating cyclic AMP levels are low in diabetics [28], and that experimental atherosclerosis lesions in animals contain lower cyclic AMP levels than normal artery [29].

Acknowledgements. The skillful technical work of Mr. Jim Donnelly and Mrs. Nora Copeland and the careful preparation of the manuscript by Mrs. Melanie Hilary and Miss Andree Best are gratefully acknowledged. The work was supported by grants from the British Heart Foundation and the Department of Health and Social Services (Northern Ireland). 


\section{References}

1. Ross R, Glomset JA (1976) The pathogenesis of atherosclerosis. N Engl J Med 295:369-377, 420-425

2. Ross R, Vogel A (1978) The platelet-derived growth factor. Cell 14: $203-210$

3. Ross R, Glomset JA (1973) Atherosclerosis and the arterial smooth muscle cell. Science 180: 1332-1339

4. Stout RW, Bierman EL, Ross R (1975) Effect of insulin on the proliferation of cultured primate arterial smooth muscle cells. Circ Res 36: 319-327

5. Sutherland EW, Robison GA (1969) Role of cyclic AMP in the control of carbohydrate metabolism. Diabetes 18: 797-819

6. Haslam RJ, Davidson MML, Davies T, Lynham JA, McClenaghan MD (1978) Regulation of platelet function by cyclic nucleotides. Adv Cyclic Nucleotide Res 9: 533-552

7. Pastan I (1975) Cyclic AMP and the malignant transformation of cells. Adv Metab Disorders 8: 377-383

8. Rutherford RB, Ross R (1976) Platelet factors stimulate fibroblasts and smooth muscle cells quiescent in plasma serum to proliferate. J Cell Biol 69: 196-203

9. Taggart H, Stout RW (1980) Control of DNA synthesis in cultured vascular endothelial and smooth muscle cells. Atherosclerosis 37: $549-557$

10. Jaffe EA, Nachman RL, Becker CG, Minick CR (1973) Culture of human endothelial cells derived from umbilical veins identification by morphologic and immunologic criteria. J Clin Invest 52: $2745-2756$

11. Gimbrone MA, Cotran RS, Folkman J (1974) Human vascular endothelial cells in culture. J Cell Biol 60:673-684

12. Jaffe EA, Hoyer LW, Nachman RL (1973) Synthesis of antihaemophilic factor antigen by cultured human endothelial cells. J Clin Invest 52: 2757-2764

13. Stout RW (1977) The effect of insulin and glucose on sterol synthesis in cultured rat arterial smooth muscle cells. Atherosclerosis $27: 271-278$

14. Lowry OH, Rosebrough NJ, Farr AL, Randall RJ (1951) Protein measurement with the Folin phenol reagent. J Biol Chem $193: 265-275$

15. Stout RW (1978) Relative insensitivity to glucagon of sterol synthesis in cultured rat aortic smooth muscle cells. Effect of dibutyryl cyclic AMP. Diabetologia 15:323-326

16. Pastan I (1975) Regulation of cellular growth. Adv Metab Disorders $8: 7-16$

17. Friedman DL (1976) Role of cyclic nucleotides in cell growth and differentiation. Physiol Rev 56: 652-708

18. Bar RS, Peacock ML, Spanheimer RG, Veenstra R, Hoak JC
(1980) Differential binding of insulin to human arterial and venous endothelial cells in primary culture. Diabetes 29:991-995

19. Gimbrone MA jr (1976) Culture of vascular endothelium. Prog Hemostasis Thromb 3: 1-28

20. Albers JJ, Bierman EL (1976) The effect of hypoxia on uptake and degradation of low density lipoprotein by cultured human arterial smooth muscle cells. Biochem Biophys Acta 424: $422-429$

21. Greenburg GB, Hunt TK (1978) The proliferative response in vitro of vascular endothelial and smooth muscle cells exposed to wound fluids and macrophages. J Cell Physiol 97:353-361

22. Bierman EL, Stein O, Stein Y (1974) Lipoprotein uptake and metabolism by rat aortic smooth muscle cells in tissue culture. Circ Res 35: 136-150

23. Weinstein DB, Carew TE, Steinberg D (1976) Uptake and degradation of low density lipoprotein by swine arterial smooth muscle cells with inhibition of cholesterol biosynthesis. Biochim Biophys Acta 424: 404-421

24. Tateson JE, Moncada S, Vane JR (1977) Effects of prostacyclin (PGX) on cyclic AMP concentrations in human platelets Prostaglandins 13:389-397

25. Miller OV, Johnson RA, Gorman RR (1977) Inhibition of $\mathrm{PGE}_{1}$-stimulated cAMP accummulation in human platelets by thromboxane $\mathrm{A}_{2}$. Prostaglandins 13:599-609

26. Silberbauer K, Schernthaner $G$, Sinzinger $H$, Piza-Katzer $H$ Winter M (1979) Decreased vascular prostacyclin in juvenileonset diabetes. N Engl J Med 300:366-367

27. Halushka PV, Luric D, Colwell JA (1977) Increased synthesis of prostaglandin E-like material by platelets from patients with diabetes mellitus. N Engl J Med 297: 1306-1310

28. Feinglos MN, Drezner MK, Lebovitz HE (1978) Measurement of plasma adenosine 3', 5'-monophosphate. J Clin Endocrinal Metab 46: 824-829

29. Numano F, Maezawa H, Shimamoto T, Adachi K (1976) Changes of cyclic-AMP and cyclic AMP phosphodiesterase in the progression and regression of experimental atherosclerosis. Ann NY Acad Sci 275:311-320

Received: 16 April 1981

and in final form: 17 August 1981

Professor R. W. Stout

Department of Geriatric Medicine

The Queen's University of Belfast

Whitla Medical Building

97 Lisburn Road

Belfast BT9 7BL, Northern Ireland 